\title{
Heterogeneous Implementation of CSR in an MNE: The Role of Subsidiaries' Institutional Contexts and Behaviors
}

Anne Jacqueminet

Ph.D. awarded by HEC Paris, France (June 2015)

\section{BIG Question:}

\section{"Beyond their diverse institutional contexts, why do we observe such heterogeneity in the way the subsidiaries of an MNE implement corporate social responsibility practices?"}

\section{Introduction}

Mounting pressures to meet corporate social responsibility (CSR) requirements urge organizations to adopt new practices and elaborate responses. Theorizing the role of external demands and organizational responses to such normative pressures is at the heart of neo-institutional theory, but further effort is needed to better understand the complex case of MNEs (Kostova, Roth \& Dacin, 2008). Indeed, conformity to external norms or lack thereof in MNEs is not a fully intended and coordinated strategic response (Crilly, Zollo \& Hansen, 2012). MNEs are not monolithic, and conformity levels are neither homogeneous across the MNE's entities nor stable over time. Some works have looked at institutional demands influencing subsidiaries' decisions, but they have paid rather limited attention to the dynamic dimension of conformity processes and to the strategic role of subsidiaries whose behavior is often reduced to mere isomorphism. Overall, the conceptualization of conformity needs to be further adapted to the case of MNEs, since: (1) within an MNE, conformity is heterogeneous because not only pressures but also responses vary across subsidiaries, (2) subsidiary conformity is an intra-organizational matter, and (3) practice implementation is a dynamic process.

Since the MNE is not monolithic, the right level of analysis to study institutional pressures is not the organization's context, but rather the subsidiaries' contexts. In fact, on top of their industry, the subsidiaries are embedded in two other fields: the local institutional field and the intra-organizational institutional field. This typology of institutional fields is consistent with international business (IB) literature according to which MNEs need to address both global integration and local responsiveness. Each subsidiary is torn between pressures for consistency within the MNE and isomorphic pressures from the differentiated local environments. Several international strategy scholars extended institutional arguments to the case of MNEs' subsidiaries. These works include studies of "legitimacy spillovers" within MNEs (Kostova \& Zaheer,
1999) and "institutional duality" (Hillman \& Wan, 2005; Kostova \& Roth, 2002) and emphasize the isomorphic pressures subsidiaries undergo. By contrast, I argue that an MNE's subsidiaries can react strategically to new normative demands and go beyond passive isomorphism. In particular, subsidiaries can devote more or less attention (Ocasio, 1997) to their internal and local constituents' demands, which results in varying implementation levels. There is a need to better conceptualize subsidiaries' attention and to understand why attention levels vary within MNEs.

The potential for decoupling practices from discourse within MNEs is particularly high as MNEs produce a lot of legitimizing discourse. However, works on such decoupling or conformity within MNEs remain scarce. A noticeable exception is the article by Crilly, Zollo and Hansen (2012), in which the authors conclude that decoupling is not necessarily a "calculated deception" from the headquarters because managers have discretion at all levels of the organization. In MNEs, decoupling is the misalignment between the commitments of the headquarters and the actions of the subsidiaries. Hence, decoupling occurs between various entities of the organization and there is variety in conformity levels across entities. Therefore, we need to understand the subsidiaries' conformity motivations to better explain intra-organizational heterogeneity. This dissertation aims to better articulate the role of the headquarters, subsidiaries and the way the subsidiaries perceive the policy considered.

In the MNE context, I argue that the level of implementation of practices varies over time, from one subsidiary to the next and from one practice to the next. Again, an MNE's subsidiaries are embedded in several fields simultaneously: the parent organization, the industry and the country. As a result, a given subsidiary is pressed to implement practices that each are diversely institutionalized in its various fields. We do not know much about how this complex institutional setting influences over time the implementation mechanisms within MNEs. In addition, empirical research on decoupling and conformity mechanisms has focused on single practices (e.g., TQM, LTIP, accountability). As a result, research on conformity has overlooked the role of the practices'idiosyncratic differences in explaining varying and evolving levels of implementation. 


\section{Summary of the Dissertation Research}

To address the gaps described above, this dissertation, which consists of three essays, focuses on CSR practices within one large MNE (over 200,000 employees in 2012) headquartered in Europe and operating in gas and energy production, energy services and environmental services. It relies on a rich set of data (3 rounds of surveys among over 400 top managers of the subsidiaries, interviews, and archival data) on the implementation of CSR practices by up to 101 of the MNE's subsidiaries located in 30 countries. In particular, the surveys conducted in 2012, 2013, and 2014 cover the implementation level of 25 practices, attention to stakeholders' demands, relationships with the headquarters as well as other subsidiaries, level of autonomy, and perception of the CSR issues in terms of their impact of the subsidiary's performance, their consistency with the subsidiary's values, and their complexity. The CSR issues considered are environmental biodiversity, gender equality, and occupational health and safety, as those are among the MNE's priorities, apply to all subsidiaries regardless of their activity, display varying levels of maturity in the MNE and relate to very different CSR domains.

In terms of methods, depending on both the research question and the nature of the outcome of interest, various analyzing techniques were used, including linear regressions with mediating and moderating effects, simultaneous equation modeling, and Fuzzy Set qualitative comparative analysis (FsQCA).

The first essay of this dissertation improves our understanding of why MNEs' subsidiaries heterogeneously implement practices. It reveals the strategic nature of subsidiaries' responses to institutional demands, both by shedding light on the role of subsidiaries' attention to the demands of their internal and external constituents and by showing that peers' norm-conforming behavior influences the level of attention these demands receive. I find that while the conformity of external peers-i.e., local rivals - to the CSR norm directs the attention of the subsidiaries toward the demands of external constituents at the expense of those from the MNE headquarters, the conformity of internal peers-i.e., close subsidiaries within the MNE-increases subsidiaries'attention to both external constituents' and headquarters'demands, resulting in varying levels of practice implementation (see also: Durand \& Jacqueminet, 2015).

The second essay of my dissertation provides a model for subsidiary conformity through which formal policies are implemented into concrete practices in MNEs. I find that subsidiary conformity results from the combination of compliance to headquarters' guidelines, internal mimicry, and internalization mechanisms. More specifically, the pressures from the headquarters related to a given CSR issue as well as the conformity of other subsidiaries increase a subsidiary's level of conformity. And the consistency of the headquarters' policy with the subsidiary's values, because it triggers policy internalization, increases the subsidiary's level of conformity, and conditions the positive effects of both peers' conformity and pressures from the headquarters. These results point to the need to better articulate compliance, conformity, and internalization within complex organizations.
The third essay explains the variation in practice implementation level over time given the practices' specific characteristics. Three attributes of the practices-complexity, consistency with subsidiaries' values and performance advantage - as well as the various levels of institutionalization of the practices influence the conformity paths they follow. The results of the FsQCA analysis show that (1) periods of conformity and decoupling more often alternate than endure, (2) the institutionalization of an issue in both the subsidiary's country and its industry is crucial for sustained implementation, and (3) practices'lack of consistency with subsidiaries'values is the main driver of enduring decoupling.

\section{Contributions for Research and Practice}

Previous works have underlined the unique situation of an MNE's subsidiaries that have to address demands from their headquarters and from their local environment simultaneously (Rosenzweig \& Sinh, 1991; Hillman \& Wan, 2005; Kostova \& Roth, 2002). But their responses are often depicted as passive. In this dissertation, I argue that subsidiaries conform to corporate policies in a strategic way. Thus, this dissertation contributes to research on subsidiaries'strategies by defining concepts such as subsidiaries' attention, conformity, and policy internalization.

In the international management context, the role of attention (Ocasio, 1997) has mostly been study at the headquarters' level: international attention (Bouquet, Morrison \& Birkinshaw, 2009) and attention to the subsidiaries (Ambos, Andersson \& Birkinshaw, 2010; Bouquet \& Birkinshaw, 2008). In the first essay of this dissertation, I shift the focus from headquarters' attention to the subsidiaries' attention as a strategic process which is instrumental in the implementation of corporate policies within MNEs. I define subsidiaries' attention to demands as comprising their noticing of these demands, their focusing of time and effort on understanding them, and their elaborating a response strategy. Thus, I advance our understanding of how subsidiaries strategically address their dual embeddedness in the MNE and in their local environment.

Most recent works on organizational conformity present it as a strategic behavior, but the potential for an MNE's subsidiaries to strategically design their conformity to corporate policy has received little attention so far. In the second essay of this dissertation, I propose a model for subsidiary conformity defined as the extent to which the subsidiary implements practices that are consistent with the corporate policy. This definition emphasizes the strategic role the subsidiaries play in MNEs' conformity. In addition, my findings suggest that subsidiary conformity does not solely depend on the demands from the headquarters, but also on the behavior of their peers and on the subsidiary's perception of the policy.

Previous works in the international management context have studied policy internalization as an outcome (Björkman, Ehrnrooth, Smale \& John, 2011; Kostova \& Roth, 2002) and defined typologies of subsidiaries based on their level of policy internalization and implementation. My dissertation contributes to this body of literature by looking at the 
complex relationship between internalization and conformity. I define subsidiaries' internalization of a policy as the mechanism through which the subsidiaries get committed to the policy because of its consistency with their values. My results show that internalization is core to the understanding of intra-organizational conformity as it not only increases subsidiaries' conformity but also influences the way they process intra-organizational pressures.

In the third essay of this dissertation, I find that the implementation of practices over time depends on (1) the level of institutionalization of the practices in the MNE, the subsidiaries' industry, and their country and (2) the way the subsidiaries perceive the practices. The findings of this essay therefore talk to research on the diffusion of innovations in MNEs (e.g., Lin \& Ho, 2011). Previous work focuses on technological innovations and on the innovations' attributes that favored their adoption. But I find that, for normative innovations, the inner attributes of the practices are not the sole explanation for their adoption as their institutionalization levels also matter.

My dissertation also has practical managerial implications as it helps an MNE's headquarters understand why conformity levels vary across the MNE's subsidiaries and how they evolve over time. More specifically, my work suggests that subsidiary conformity - which is desirable for the MNE's top managers-is not achieved through top down enforcement of policies only. The CSR example shows that the initiatives that emerge locally from the demands of external constituents can improve the subsidiaries' conformity and thus the MNE's conformity as a whole. This means that such initiatives should be encouraged and the MNE could benefit from the experience and knowledge accumulated locally by its subsidiaries, should it be shared. In addition, the pressure headquarters put on their subsidiaries might prove counter-productive in certain situations as it has limited-if any-impact on conformity for subsidiaries with low internalization of the policy. MNE's managers should consider granting subsidiaries some leeway in the implementation of CSR practices, depending on how much they internalize the policy. Communication and monitoring efforts should be concentrated toward subsidiaries that do not perceive the policy favorably. Moreover, intra-organizational emulation appears favorable for the implementation of practices and subsidiaries'conformity. Managing the subsidiaries' conformity strategies through a strategic allocation of resources should therefore be a major concern for the headquarters' when attempting to diffuse a new policy. A few central subsidiaries in each industry or country could act as champions of the corporate policy and foster its diffusion among their network of peer subsidiaries. However, this dissertation also suggests that CSR implementation varies over time. The top managers of MNEs should therefore monitor their non-financial reporting very carefully on a regular basis and combine performance indicators with indicators that track the implementation of desired practices. Finally, as far as subsidiaries' managers are concerned, they can take away that CSR conformity through the faithful implementation of group policies as well as implementation of unique and innovative initiatives can help them gain attention from the headquarters and power vis-à-vis their counterparts, probably beyond CSR issues.

\section{References}

Ambos, T. C., Andersson, U., \& Birkinshaw, J. 2010. What are the consequences of initiative-taking in multinational subsidiaries. Journal of International Business Studies, 41 (7): 1099-1118.

Björkman, I., Ehrnrooth, M., Smale, A., \& John, S. 2011. The determinants of line management internalisation of HRM practices in MNC subsidiaries. The International Journal of Human Resource Management, 22(8): 1654-1671.

Bouquet, C., \& Birkinshaw, J. 2008. Weight versus voice: How foreign subsidiaries gain attention from corporate headquarters. Academy of Management Journal, 51(3): 577-601.

Bouquet, C., Morrison, A., \& Birkinshaw, J. 2009. International attention and multinational enterprise performance. Journal of International Business Studies, 40(1): 108-131.

Crilly, D., Zollo, M., \& Hansen, M. T. 2012. Faking it or muddling through? Understanding decoupling in response to stakeholder pressures. Academy of Management Journal, 55(6): 1429-1448.

Durand, R., \& Jacqueminet, A. 2015. Peer conformity, attention, and heterogeneous implementation of practices in MNEs. Journal of International Business Studies, 46(8), 917-937.

Hillman, A., \& Wan, W. P. 2005. The determinants of MNE subsidiaries' political strategies: Evidence of institutional duality. Journal of International Business Studies, 36(3): 322-340.

Kostova, T. \& Roth, K. 2002. Adoption of an organizational practice by subsidiaries of multinational corporations: institutional and relational effects. Academy of Management Journal, 45(1): 215-233.

Kostova, T., Roth, K., \& Dacin, M. T. 2008. Institutional theory in the study of multinational corporations: A critique and new directions. Academy of Management Review, 33(4): 994-1006.

Kostova, T., \& Zaheer, S. 1999. Organizational legitimacy under conditions of complexity: The case of the multinational enterprise. Academy of Management Review, 24(1): 64-81.

Ocasio, W. 1997. Towards an attention-based view of the firm. Strategic Management Journal, 18(S1): 187-206.

Rosenzweig, P. M., \& Singh, J. V. 1991. Organizational environments and the multinational enterprise. Academy of Management Review, 16(2): 340-361.

Anne Jacqueminet (anne.jacqueminet@unibocconi.it) is Assistant Professor of Management at Bocconi University, Milan. She received her PhD in strategy from HEC Paris. Her research seeks to explain conformity within multinational enterprises and subsidiaries' implementation of practices and she focuses on relational as well as strategic drivers. She is particularly interested in sustainability issues, corporate social responsibility, and ethics. 